\title{
Editorial \#4
}

Os editores

\section{O dossier temático, os ensaios e a entrevista}

Ao completar o seu segundo ano de vida, a Aniki publica o seu primeiro dossier temático organizado por um editor convidado. Vicente Sánchez-Biosca, professor catedrático de Comunicação Audiovisual na Universidade de Valência, é o autor de várias obras de referência sobre a história do cinema espanhol durante a Guerra Civil de 19361939 e tem-se interessado, de modo geral, pelas relações entre cinema, história e memória. O dossier que organizou para este número da Aniki intitula-se "Os arquivos fílmicos e a memória: documentos e ficções" e é apresentado em texto autónomo no início da respetiva secção. Todos os textos do dossier temático foram submetidos a um processo de avaliação cega por pares.

A secção de Ensaios da Aniki recebe permanentemente submissões fora do tema do dossier. Neste número, esta secção conta com dois textos. O primeiro, de Roberto Cavallini, analisa os filmes de Lisandro Alonso a partir de uma utilização crítica do conceito de "slow cinema" e, de maneira original, leva em conta o papel do som nas estratégias formais do realizador argentino. O segundo texto, de Ana Bela Morais, explora o arquivo da Comissão de Censura recentemente integrado nas coleções do Arquivo Nacional da Torre do Tombo. A partir do estudo de um caso em particular, o processo de censura do filme A Promessa (António de Macedo, 1972), a autora revela a mecânica processual da censura portuguesa durante o período político do Marcelismo. Escolhendo o cinema de autor internacional ou um assunto central da história do cinema português, optando por uma análise formal cuidada ou uma investigação aturada em fontes documentais, estes dois artigos são um exemplo da diversidade de temas e de abordagens metodológicas que a Aniki pretende encorajar e dar visibilidade.

A secção de Entrevistas articula-se com o dossier temático editado por Vicente Sánchez-Biosca, apresentando uma conversa de Anita Leandro com os cineastas Luiz Alberto Sanz e Lars Säfström. Esta entrevista fixa um encontro, em 2014, entre o autor brasileiro e o autor sueco que, no final da década de 60, trabalharam juntos na Film Centrum, cooperativa de produção, realização e distribuição de filmes independentes, radicada na Suécia. Para além das suas biografias pessoais, a entrevista traça a relação entre ambos, de que resultaram vários projetos fílmicos revolucionários, assim como a atividade da Film Centrum e da importância do material de arquivo. 


\section{As recensões de livros e conferências}

Nesta edição publicam-se recensões a quatro livros além do relatório sobre o XVIII Encontro da Sociedade Brasileira de Estudos de Cinema e Audiovisual - Socine. Abrindo a secção, Touching from a Distance, de Jorge Martins Rosa, é a recensão de Imagem, Corpo, Tecnologia: A Função Háptica das Novas Imagens Tecnológicas, de Patrícia Silveirinha Castello Branco (2013), baseado na tese de doutoramento desta em Ciências da Comunicação. Rosa considera que este estudo que, adverte, recorre a argumentação algo hermética justificando-se tal pela pluridimensionalidade do tema e pela complexidade das teorias que lhe servem de suporte - é um marco na investigação sobre imagem e media.

O investigador Leandro Mendonça revisitou uma obra que se tornou incontornável nos estudos sobre o cinema durante o Estado Novo. Mendonça procura explicar a necessidade de desconstruir a história do cinema e visa clarificar porque é que $O$ cinema sob o olhar de Salazar produziu uma ligação virtuosa entre a pesquisa histórica sobre o período do Estado Novo e a história do cinema português.

Patrícia Santos Pedrosa leu criticamente Os Cinemas de Lisboa. Um fenómeno urbano do século $X X$, da historiadora de arte Margarida Acciaiuoli. Pedrosa explica que o livro contempla o período compreendido entre o final do século XIX e o princípio do século XXI, desfiando, com enquadramento amplo, a relação próxima entre a cidade e os espaços onde a história do cinema também acontece e pode ser contada: os cinemas. Esta "viagem", no espaço e no tempo, por Lisboa através dos seus cinemas sublinha como a história da cidade se projetou na arquitetura das suas salas de cinema e como foram mudando, uma e outras, a par.

Illusions in motion: media archaeology of the moving panorama and related spectacles, de Erkki Huhtamo, foi alvo de recensão por Rafael Freire. Freire sustenta que, ao investigar exaustivamente os panoramas móveis, mais do que esgotar o tema, esta obra faz surgir novas indagações e questionamentos. Afirma que esta obra não deve ser um exemplo de exaustividade e rigor que intime outros investigadores a complementá-la mas que deve ser tomado como convite para estudar a eventual presença dos panoramas móveis em territórios que não foram abordados por Huhtamo, como a América Latina.

O relatório sobre o XVIII Encontro da Sociedade Brasileira de Estudos de Cinema e Audiovisual - Socine, que, em 2014, decorreu na Universidade de Fortaleza, reflete sobre a dimensão e organização do evento. Nele, Pereira, Baggio e Penafria sintetizam o teor de algumas das comunicações apresentadas no encontro, centrando-se nas produções cinematográficas latino-americanas mais recentes mas não esquecendo o cinema africano. Explica-se que a questão da visibilidade desta produção afro-latino-americana, as políticas de financiamento e distribuição, bem como a importância de festivais 
temáticos nos países de expressão portuguesa e a própria colocação de filmes em plataformas digitais foram abordadas em particular em "A coprodução no espaço lusófono", promovida pelo Seminário Temático Cinema em português: aproximações - relações.

\section{As exposições e festivais}

Dialogando com o tema deste número da Aniki, os dois primeiros textos da secção "Exposições e festivais" focam-se sobre dois acontecimentos intimamente ligados à questão dos arquivos. O primeiro concentra-se sobre uma exposição realizada no Eye de Amsterdão (o museu do cinema neerlandês) e dedicada a uma das figuras mais importantes dos primórdios do cinema europeu, o distribuidor Jean Desmet (1875-1956). Desmet, cujas atividades cessam progressivamente a partir de 1916, legou-nos um património considerável, constituído por mais de 900 filmes (muitos deles coloridos), vários milhares de cartazes e de programas cinematográficos. A investigadora Eline Grignard (Sorbonne Nouvelle - Paris 3) recorda, no seu texto, a importância desta coleção (classificada como património mundial da UNESCO) e evoca os desafios de expor este tipo de materiais. Um segundo texto assinado pela investigadora Sabrina Negri (Chicago University) evoca a primeira edição do festival "The Nitrate Picture Show", realizado em Rochester, na célebre George Eastman House. O festival apresentou unicamente cópias em nitrato de nove filmes de diferentes épocas e proveniências, durante várias décadas banidos das salas de projeção por razões de segurança. Tal como assinala a autora do texto (que trabalhou como arquivista no Museo Nazionale del Cinema di Torino), a decisão de mostrar estas cópias, que se transformaram numa espécie de "fruto proibido" dos investigadores, apoia-se sobre uma visão da cinefilia que valoriza tanto a importância do filme enquanto artefacto material e obra de arte, como a experiência coletiva de assistir a ume projeção numa sala de cinema.

O terceiro texto da secção, assinado pelo investigador e comissário Enrico Camporesi (Sorbonne Nouvelle - Paris 3 / Centre Georges Pompidou), não é um texto crítico. Camporesi escreve na primeira pessoa sobre a experiência e as questões que se lhe colocaram enquanto curador da primeira exposição monográfica do fotógrafo e cineasta experimental Paolo Gioli nos Estados Unidos. Realizada na Microscope Gallery de Nova Iorque, a exposição articulou-se em torno dum motivo - a face - para assim propor uma combinação de obras fotográficas e cinematográficas. 